\title{
Analysis on Influencing Factor about Decision-Making on Concession Term of PPP Beijing Subway
}

\author{
Qianru Yang ${ }^{1}$ \\ ${ }^{1}$ Economics and Management Department, North China Electric Power University \\ Beijing, 102206, China
}

Keywords: Decision-Making, PPP Beijing Subway, Influencing Factor

\begin{abstract}
In October 2005, the National Development and Reform Commission formally approved the Beijing subway metro line 4 franchising project, whichmarked that our country started the first franchise subway projects on the mainland.Beijing subway line 4 franchising project is a big important innovation of the Beijing municipal infrastructure investment and financing system reform, which not only relievescentralized pressure on the government in the construction of the subway, but also reduces the government subsidies in the operating period and is beneficial to introduce competition mechanism in the rail transportation industry, providing citizens with a high level of service.
\end{abstract}

\section{Introduction}

In October 2005, the National Development and Reform Commission formally approved the Beijing subway metro line 4 franchising project, whichmarked that our country started the first franchise subway projects on the mainland.Beijing subway line 4 franchising project is a big important innovation of the Beijing municipal infrastructure investment and financing system reform, which not only relievescentralized pressure on the government in the construction of the subway, but also reduces the government subsidies in the operating period and is beneficial to introduce competition mechanism in the rail transportation industry, providing citizens with a high level of service.

Then Beijing metro line 14 copied the line 4 PPP mode.Beijing metro line 14 began to construct in early 2010, ranging from ZhangGuo Zhuang station to Xi Ju station, was officially open on May 5, 2013.On December 28, 2014, Beijing metro line 14 eastern was open.Beijing metro line 14 is introduced social investors adopting the PPP mode, whose market-oriented investment scale is 15 billion yuan. Beijing Infrastructure Investment Limited Companyis responsible for the line 14 investment work.

Line 16 projects, with a total investment of about $\$ 47.4$ billion, adopted the PPP modeagain, aftermode the introduction of social capital to participate in the metro construction investmentin the Beijing subway line 4, line 14using the PPP.Unlike previous models, line 16 adopted the complex PPP mode.Especially, line 16 introduced insurance equity investment in rail transit project for the first time and adopted the "equity finance + franchise" financing mode into social capital, whose total investment is 27 billion yuan.The success of the PPP mode has brought us a wider thinking.

\section{Decision-Making on Concession Term of PPP Subway}

The PPP model is a new project financing model with public and private enterprise cooperation.In 
the PPP mode, the public sector and private enterprise based on some project form mutual equal relations of cooperation, mutual investment, risk and sharing the benefits.It will combine the public sector and private companies and their advantages fully, leading to reduce the government financial pressure, and improve the quality of the project construction and operating efficiency as well.The general operation procedure of the PPP model is: public sector selection project partners (private companies) $\rightarrow$ establish project concession agreement $\rightarrow$ set up a franchise company $\rightarrow$ project financing $\rightarrow$ project construction $\rightarrow$ project operation and management $\rightarrow$ project handover.[1]

In the PPP mode, the public and private enterprises take part in the project based on the cooperation of the franchise agreement.The determination of concession period is the core terms and a important parameter of the franchise contract, and the core problems of the PPP project bidding and the franchise agreement negotiations. If the concession period is too long, itwill make the government and the public interests suffer loss, however, too short leads to private investors can't get the expected return on investment.

According to the franchise agreements, the concession period can be divided into two categories, which are fixed concession period and elastic concession period.Fixed concession period refers to that, after the government and the private economic entity to determine the concession periodthe construction and operation of the project must be in strict accordance with the transfer of project time limit.Unless a franchise agreement specified in the special circumstances (such as force majeure factors), it shall not be arbitrarily change the concession period length.

Considering the uncertainty of the PPP project more risk factors,elastic concession periodis based on the net present value (NPV) of the auction. The government generally selectsthe lowest net present value as the winning bidder, where concession period is the net present value reaching the date of the specified value in the agreement.

At present, the concession period decision method is developing towards the two main directions. One is fixed concession period decision method, including net present value method, the game theory method and the Monte Carlo Simulation Method.The second is the elastic concession period decision methodbased on the above methods, including the Least Present Value of Revenue (LPVR) and the Least Present Value of Net Revenue (LPVNR).Considering there may be adverse factors of the government and the peoplein the elasticity of concession period, for example, the project company may only stand for their own interests to ensure the quality of the infrastructure concession periodregardless of the use continued after the handover.The government may spend a huge sum of money each year to maintain, deviating from the original intention of "win-win".So this paper only studies on the fixed concession period.

\section{Analysis on Influencing Factor about Decision-Making on Concession Term of PPP Beijing Subway}

In the decision-making of fixed concession period, the concession period decision model based on net present value method is a foundation, and based on game theory and the Monte CarloSimulation Method are addition.Because the net present value method is intuitive, simple, easy to operate, combined with the project basic information, whichis easily calculated the feasible region of the concession period, it becomesthe most commonly used in practice in the PPP project concession period decision.Now taking Beijing metro line 4 for an example, analysis the influence factors of concession period decisionaccording to the three methods.

The Total Project Investment and Operating Cost. The PPP mode, franchising period is proportional to the initial investment cost and operation cost of the project.As the more project total investment is, the longer it will be used to withdraw the investment.In order to achieve the expected 
investment return, concession period also should be longer. While the higher operating costs are, the less the annual net cash flows are and the longer investors recover time is, then it should appropriately extend franchising period to ensure that the investor's reasonable profit.

Operating costs mainly include facilities maintenance and repair costs, production costs, raw materials costs, labor cost, business tax and surcharges, marketing costs, depreciation, amortization and other management fees, fund raising cost, financial expenses such as interest expense.Among them, depreciation and amortization expense do not really have cash outflows, therefore, it needs to deduct from the total operating costs.[2]

Beijing subway line 4 projects concession period including construction and franchise operation period, in which the construction period is 4 years and the concession period is 30 years.According to the preliminary design budgetary estimate, Beijing metro line 4 projects has a total investment about 15.3 billion yuan. The investment in metro system is highly dependent on the government, facing the expanding subway construction scale; theproblem of construction fund shortage is obvious.The PPP model introduces social capital into investment and financing, ease the tight money, but also requires a certain return on investment, then the franchising period will be longer.In the period of operations, the operating costs are huge, for instance Beijing Hong Kong metro is responsible for all of maintenance and upgrading work of the line, equipment and facilities, expected close to 10 billion yuan investment.So when making a concession period decision, it is essential to estimate the costs and expensesreasonably.

Operating Income.The length of concession period isinversely proportional to the operating income. The more operationincome in the franchising period each year is, the shorter the time of initial investmentthe investors recovering are, the shorter the corresponding concession period is.It will be affected by operating income, operating costs, depreciation and the impact of income tax with net present value method in the project .It is shown as follow:

Business net cash flow = operating income - (operating costs-depreciation) - tax =operating income $\times$ (1-tax rate) -out-of-pocket cost $\times(1$ - tax rate $) \mathrm{x}+$ depreciation $\times$ tax rate

Passengerfares are the core of operating income in the metro project, whose confirmation directly determines whether the whole market operation succeeds. In the past, rail transit project directly depended onthe fiscal investment, and thenoperated directly by the financial allocation of state-owned enterprises. Whether the project is profitable is not important, and there is no difference between government pricing and market pricing.The introduction of PPP financing model, social capital is involved in the construction of investment, profits become the basis of social capital investment. Pricing power ofline 4 project is grasped by the government, therefore the key to the project implementation is thegovernment pricing in order to ensure the public welfare and coordination,and the market pricingfor the purpose of profits.[3]

The Beijing adopted a policy of the unity of the 2 yuan subway fares before, whichwent against the original line 4 projects take taxi fares based on mileage.If the government does not provide subsidies to the franchise company, franchise company's profit targets will not be able to realize, causing the project is unable to carry out and also hitspositivity of the social capital to participate in infrastructure projects investment and financing of public service,leading to public-private partnership model can't continue to popularization and application in other projects.To accurately calculate the cost and profit, subsidies to the project can make up the gap between actual price levels and government pricing. So the further reformof public services of price formation mechanism, reasonable development, the adjustment of price mechanism and the fiscal subsidy mechanism areneeded. On December 28, 2014, it carried out a piecewise valuation model and the corresponding preferential policy, reducing the pressure on the government's subsidies. 
Internal Rate of Return. Franchise operation period was positive to rate of return on investmentinvestors expected.In the circumstances of other elements being the same, the higher the return on investmentinvestors expected is, the longer the requirements of the concession period is.Private sectors demand a certain yield, at the same time, are restricted by the highest yield public sectors set.

In line 4 projects, the rent adjustment mechanism is designed innovatively.At the beginning of the project, the government charges a small symbolic rent orall freefrom the franchise company to promote the project to mature as soon as possible. In project maturity, if the actual percentage is over predicted passenger flow for a certain, government will increase the rent appropriately to take back the government investment and avoid chartered companies using the public property to produce high yield;If proportion is lower or government pricing is lower than the predicted passenger flow measured before, government investors will reduce appropriatelythe rent and offer certain subsidy, thus ensuring the charter of the company's earnings.

Risk Sharing. The PPP project, with the feature of huge investment, long construction period and long operation period, determines it will face a variety of risk factors, including political risk, policy risk, legal risk, financial risk, economic and market risk, operational risk management and so on.Project risk is not direct influence factors, but it will influence on the concession period reflected by influencing the decision-making factors. Therefore in the Monte CarloSimulation Method,charter period is measured complementally by many risk factors,such as market demand, the construction cycle.

In line 4 project, the determination of the ratio between government investment and social investment reflects the equality and fairness for each party in the public-private partnership model, reducing the investment risk and avoiding the management risk, to make social capital profitable and arouse the enthusiasm of the private capital, finally achieving the goal of win-win.And the government is involved in A part construction of the project, so in terms of construction risk and environment risk, it basically follow the principle of "who is controlling, who is responsible for”.Beijing MTR corporation Limited is mainly responsible for the operation of the project, but in terms of operation risk and market risk, the government consider the symmetrical principle between risks and benefits, through the difference compensation to share some of the price risk and passenger flow risk.[4] these risks influence the operation cost of the project and return on investment and other factors which affect the charter period.

Other Factors. The influencing factors of franchise operation period includes other factors, such as the discount rate.The discount rate refers to the assets of the reduction as the ratio of present value of future net cash flows.For governments, the discount rate is the recognition of the social capital reasonable yields, mainly affected by interest rates and inflation.For social investors, the discount rate is the cost of capital investment projects, which refers to the social capital to invest in the PPP project the required minimum rate of return.Obviously, the bigger the discount rate is, the longer the concession period is.

There are some methods according to the government and private investors in the optimal investment proportion to the concession period, due to the proportion between investment and operating income and the internal factors has much intimate contact, which can realize the maximization of the social benefits of government and private investors expectation effect, so italso can be used as a franchise operation decision-making influence factors.

At the end of 2003, the Beijing government has been clear about the rail transit can be according to the proportion of 7:3 between the government and social investment, absorbing the investors to participate in social construction. And the division of line 4 public welfare and profitability part 
proportion was identified as $7: 3.30 \%$ of the whole project investment was completed by social investment, using public-private cooperation way to solve the problem of project financing.The remaining $70 \%$ investment is still solved by the government financial resources. It can ensure the rails transit projects as well as the public goods of public welfare, to attract the social capital and expand the source of funds.

\section{Conclusion}

How to determine the concession period of the infrastructure PPP project is gradually becoming the focus of academic circles in recent years.Because the PPP project investment in general will be much higher, its service level is influenced by time directly.If the concession period is unreasonable, it will have an impact on government and private investors. On one hand, it will lead investors can't gain expected revenues during the charter period. On the other hand, it will bring muchheavy burden on government subsidies.Therefore, formulating reasonable concession period is vital for the success of the PPP project.The Beijing subway line 4 project is a successful example of using the PPP pattern in China, whose concession period decision effect is significant.Of course, there are many factors affecting the concession period whichare not quantitative c, such as the influence of the relevant laws and regulations. These are worth our deeper study in the future.

\section{Acknowledgements}

Fund Project: Application in Beijing Metro Project of PPP

\section{References}

[1] Zhao Xin,The application of PPP project financing mode and practice---take the Beijing subway line 4 financing for example,Liaoning Economy,2008

[2] Zhang Jihong,Analysis on the PPP project charter period impact factors, Economic Forum,2015(9)

[3] Zhao Xianli,Li Zijun,Public-private partnership in the underground economy- Beijing metro line 4 projects experience and significance,Urban Insight,2012

[4] Xie Junrong,Lu Yanyan,The PPP mode application in Beijing metro line 4,Finance and Accounting,2013(4) 